\title{
Involvement of nucleus accumbens dopamine D1 receptors in ethanol drinking, ethanol-induced conditioned place preference, and ethanol-induced psychomotor sensitization in mice
}

\author{
Amine Bahi • Jean-Luc Dreyer
}

\begin{abstract}
Rationale Dopamine D1 receptor (D1R) signaling has been associated to ethanol consumption and reward in laboratory animals.

Objectives Here, we hypothesize that this receptor, which is located within the nucleus accumbens (NAc) neurons, modulates alcohol reward mechanisms.

Methods To test this hypothesis, we measured alcohol consumption and ethanol-induced psychomotor sensitization and conditioned place preference (CPP) in mice that received bilateral microinjections of small interference RNA (siRNA)-expressing lentiviral vectors (LV-siD1R) producing D1R knock-down. The other group received control (LV-Mock) viral vectors into the NAc.

Results There were no differences in the total fluid consumed and also no differences in the amount of ethanol consumed between groups prior to surgery. However, after surgery, the LV-siD1R group consumed less ethanol than the control group. This difference was not associated to taste neophobia. In addition, results have shown that downregulation of endogenous D1R using viral-mediated siRNA in the NAc significantly decreased ethanol-induced behavioral sensitization as well as acquisition, but not expression, of ethanol-induced place preference.
\end{abstract}

\footnotetext{
A. Bahi $(\bowtie)$

Department of Anatomy, Faculty of Medicine \& Health Sciences,

United Arab Emirates University,

Tawam Medical Campus, PO Box 17666, Al Ain,

United Arab Emirates

e-mail: amine.bahi@uaeu.ac.ae

\section{J.-L. Dreyer}

Division of Biochemistry, Department of Medicine,

University of Fribourg,

Fribourg, Switzerland
}

Conclusions We conclude that decreased D1R expression into the NAc led to reduced ethanol rewarding properties, thereby leading to lower voluntary ethanol consumption. Together, these findings demonstrate that the D1 receptor pathway within the NAc controls ethanol reward and intake.

Keywords D1 receptor · Ethanol $\cdot$ Reward · Place preference - Behavioral sensitization · SCH-39166 - siRNA · Lentivitus
Abbreviations
CPP Conditioned place preference
D1R Dopamine D1 receptor
GPCR G protein-coupled receptors
EtOH Ethanol
LV Lentiviral vector
NAc Nucleus accumbens
siRNA Small interference RNA
VTA Ventral tegmental area

\section{Introduction}

Alcohol is widely consumed for its desirable effects, but unfortunately has strong addictive properties. In fact, some individuals control their alcohol consumption throughout life, but others escalate their drinking to levels that increase the risk for addiction. Nevertheless, the neurobiological and molecular bases for ethanol action on the brain and addiction processes are poorly understood. Dopamine is widely recognized as a key neurotransmitter signal involved in drugs of abuse reward, and the dopaminergic system is believed to play a crucial role in the reinforcing properties of ethanol consumption (Badanich et al. 2007; Bassareo 
et al. 2003; Di Chiara 1997; Grace 2000; Herz 1997; Koob and Weiss 1992; Oreland et al. 2011; Phillips and Shen 1996). However, the dopamine system is very complex and the role of the various dopaminergic receptor subtypes has been difficult to tease apart. The dopamine receptors can subdivided in two families: D1 family (dopamine D1 receptor (D1R) and D5R) and D2 family (D2R, D3R, and D4R) (Bordet 2004; Le Foll et al. 2009; Nieoullon and Amalric 2002; Sibley 1999; Velasco et al. 2002; Velasco and Luchsinger 1998; Verheij and Cools 2008). Most importantly, genetic studies have found associations between the dopaminergic system and alcoholism, including the identification of gene polymorphisms for some dopamine receptors (Ball and Murray 1994; Kohnke 2008; Li 2000; Tiihonen et al. 1995; Tyndale 2003), but not all reports are in agreement (Bolos et al. 1990). Thus, there is a putative genetic and physiological link between dopaminergic neurotransmission and ethanol abuse.

Several reports from research on laboratory animals suggest that the dopaminergic neurotransmission affects ethanol reward. For example, low doses of ethanol $(0.25-0.5 \mathrm{~g} / \mathrm{kg}$, i.p.) stimulated dopamine release specifically in the nucleus accumbens (NAc) and elicited pure behavioral stimulation. This finding was abolished by pretreatment with gammabutyrolactone, an agent which blocks dopamine firing and dopamine release (Di Chiara and Imperato 1988; Imperato and Di Chiara 1986). In addition, voluntary oral ethanol self-administration in alcohol-preferring Wistar rats has shown a robust increase of extracellular dopamine levels in the NAc with maximal effects at approximately 15-30 min after peak intake (Blanchard et al. 1993; Bustamante et al. 2008; Jerlhag et al. 2011; Kiianmaa et al. 1995; Nurmi et al. 1998; Weiss et al. 1993), suggesting that dopaminergic neurotransmission in the NAc may be an important factor in alcohol reinforcement. Also, the dopamine transporter together with dopamine innervation density, as determined by tyrosine hydroxylase immunostaining, was found to be lower in the NAc of the ethanol-preferring compared with that of non-preferring rats (Casu et al. 2002a, b; Zhou et al. 1995). Together, these observations suggest that alterations in dopamine transmission may drive ethanol consumption and preference.

Several dopaminergic receptors have been implicated in ethanol consumption, including D1R. Chronic ethanol intake led to bidirectional changes in the maximum number of [3H]SCH-23390 binding to striatal D1R measured $10 \mathrm{~h}$ after termination of the ethanol intake (Hamdi and Prasad 1993). In non-human primates, genetic variation in D1R influences alcohol consumption in rhesus macaques (Newman et al. 2009). Also, in rodents, chronic ethanol consumption induced a significant increase in the number of D1R sites in the caudate putamen (Lograno et al. 1993). Report with D1R knock-out mice has shown that constitutive absence of this receptor causes decreased ethanol intake as compared to their wild-type littermates (El-Ghundi et al. 1998). When infused into the NAc core or shell, the D1R antagonist $(R-(+)-7$-chloro-3-methyl-1-phenyl-1,2,4,5-tetrahydro-3-benzazepine-8-ol) "SCH-23390" dose-dependently reduced reinstatement of ethanol self-administration in rats (Chaudhri et al. 2009). In addition, in high alcohol drinking line of rats, SCH-23390 (3-30 $\mu \mathrm{g} / \mathrm{kg})$ dose-dependently decreased ethanol drinking during the first hour of access (Chaudhri et al. 2009; Cohen et al. 1997; Dyr et al. 1993; Eiler et al. 2003; Hodge et al. 1997). However, other studies with the same antagonist have shown no effect on ethanol consumption (Melendez et al. 2005; Phillips et al. 1998; Silvestre et al. 1996). Surprisingly, the D1R partial agonist ((+/-)-1-phenyl-2,3,4,5-tetrahydro-(1H)-3-benzazepine-7, 8-diol hydrochloride) (SKF-38393) also decreased alcohol intake in both rats (Cohen et al. 1999; Dyr et al. 1993; Silvestre et al. 1996) and mice (Ng and George 1994). We are focusing on D1 receptors expressed in medium spiny neurons, because they are expressed at high levels in the ventral striatum (Caille et al. 1996; Matamales et al. 2009; Muly et al. 2010; Podda et al. 2010) and are thought to be major regulators of dopaminergic neurons originating from the ventral tegmental area (VTA) that provide innervation to the NAc (Altier and Stewart 1999; Arias-Carrion et al. 2010; Cooper 2002; Gonzales et al. 2004; Herz 1997; McBride et al. 1999).

Given the links between dopamine, ethanol intake, and dopamine D1 receptor, we hypothesize in the current study that knocking-down the D1R mRNA in the nucleus accumbens will alter motivational aspects of ethanol drinking, behavioral sensitization, and conditioned place preference (CPP) during both the initiation and maintenance of ethanol reward.

\section{Materials and methods}

Animals

C57BL/6 male mice (25 to $35 \mathrm{~g}$ ) were housed in groups of five per cage for at least 7 days before use and were maintained on a 12:00/12:00 hour light/dark cycle (lights off at 7:00 am) with food and water available ad libitum. All animal care and use were in accordance with the National Institutes of Health Guide for the Care and Use of Laboratory Animals. All experimental procedures were approved by the local research ethics committee.

Drugs

Ethanol $(2 \mathrm{~g} / \mathrm{kg}, 20 \% \mathrm{v} / \mathrm{v})$ was obtained by dilution of absolute ethanol in isotonic saline $(0.9 \% \mathrm{NaCl})$. The specific 
dopamine D1 receptor antagonist (6aS-trans)-11-chloro6,6a, 7,8,9,13b-hexahydro-7-methyl-5Hbenzo[d]naphth[2, 1-b]azepin-12-ol hydrobromide "SCH-39166" (12.5 and $50 \mu \mathrm{g} / \mathrm{kg}$ ) (Sigma) was dissolved in isotonic saline and administered s.c. $(10 \mathrm{ml} / \mathrm{kg}) 15 \mathrm{~min}$ before ethanol.

Virus preparation of D1R small interference

RNA-expressing vectors and viral delivery

The cloning of the dopamine D1 receptor small interference RNA (siRNA)-expressing lentiviruses has been described previously in detail (Ortiz et al. 2010). Briefly, three 19-nucleotide D1R siRNA sequences were added to the U6 promoter by PCR. The amplicon was then purified, digested with $B a m \mathrm{HI} / X h o \mathrm{I}$ and ligated into the pTK431 previously digested with the same enzymes. Positive clones were confirmed by digestion and sequencing. Preparation of lentiviral vectors was initiated by triple transfection of HEK293T cells by calcium phosphate method using pTK431 together with pDeltaNRF and pMDG-VSV. Cells were harvested $72 \mathrm{~h}$ later and viruses were concentrated from the supernatant by ultracentrifugation. Vectors were resuspended in PBS-BSA and stored at $-80^{\circ} \mathrm{C}$ till use (Bahi et al. 2004a, b, 2005a, b, 2006, 2008a, b, c; Bahi and Dreyer 2008).

To deliver the viruses into the NAc, we used stereotaxic injection. Briefly, mice first anesthetized with a ketamine/xylazine mixture and installed in a stereotaxic frame. Using a precision Hamilton micro-syringe with a $26 \mathrm{G}$ needle, mice were bilaterally infused with viral solution using the following coordinates: $+1.6 \mathrm{~mm}$ antero-posterior, $\pm 0.8 \mathrm{~mm}$ lateral from the bregma, and $4 \mathrm{~mm}$ ventral from the skull (Franklin and Paxinos 1996). Viruses were infused at a rate of $0.1 \mu \mathrm{l} / \mathrm{min}$ for $5 \mathrm{~min}$ (final volume $0.5 \mu \mathrm{l} /$ site) and the Hamilton micro-syringe was held in place for an additional 10 min before being withdrawn slowly. Following surgery, mice were allowed to recover for 7 days before undergoing the behavioral assays. Placement of the injections was determined by RT-PCR in punches from mice used to evaluate the efficacy of the shRNAmediated knock-down.

\section{Cell culture}

HEK293T cells transfected with D1R-expressing plasmid were cultured in Dulbecco's modified Eagle's medium containing 10\% fetal bovine serum. Cells were then transfected using $10 \mathrm{mg} / \mathrm{ml}$ Polybrene (Sigma) with lentiviruses expressing small interference RNA (siRNA)-expressing lentiviral vectors (LV-siD1R) or LV-Mock for 3 days before analysis of D1 receptor mRNA level.
Total RNA isolation and RT-PCR quantification

Total RNA from cells and brain tissue were isolated using Trizol (Invitrogen) and reverse-transcribed using SuperScript III reverse transcription (Invitrogen). RNA expression was analyzed by Q-PCR using SyberGreen with temperature cycling parameters consisting of initial denaturation at $95^{\circ} \mathrm{C}$ for $4 \mathrm{~min}$ followed by 40 cycles of denaturation at $94^{\circ} \mathrm{C}$ for $30 \mathrm{~s}$, annealing and extension at $64^{\circ} \mathrm{C}$ for $45 \mathrm{~s}$. PCR for the control gene, glyceraldehyde-3-phosphate dehydrogenase (GAPDH), was run with the same cycling parameters. PCR products were normalized to GAPDH as indicated in the figure legends.

Two-bottle choice drinking test and preference for non-ethanol tastants

For two-bottle choice tests, mice were singly housed, and one 10-ml pipette containing tap water and one containing increasing ethanol concentration $(3 \%, 6 \%, 10 \%, 15 \%$, and $20 \%, v / v)$ were placed on each cage. The positions of the pipettes on the cage were random and inverted every day to avoid side preference. Mice were allowed free choice of these drinking solutions for 24-h periods with simultaneous free access to food. Ethanol concentration was raised every 5 days. Ethanol intake was calculated on the basis of ethanol volume consumed after each 24 -h period, and body weights were used to calculate grams per kilogram of ethanol consumed (Bahi et al. 2011). One week after the completion of the ethanol drinking experiment, LV-Mock and LV-siD1R mice were also tested for saccharin and quinine consumption. One $10-\mathrm{ml}$ pipette always contained water and the other contained the tastant solution. Mice were serially offered saccharin $(0.04 \%$ and $0.08 \%)$ and quinine hemisulfate $(0.02$ and $0.04 \mathrm{mM})$ and intakes were calculated. Each concentration was offered for 5 days, with tube position changed every day. For each tastant, the low concentration was always presented first, followed by the higher concentration. Between tastants, mice had two bottles both containing water for 2 weeks (Bahi 2011; Bahi and Dreyer 2011; Bahi et al. 2011).

Ethanol-induced psychomotor sensitization

The acquisition and expression of psychomotor sensitization to alcohol was investigated using a 21-day protocol. On days $1-2$, all mice received saline before being placed in the activity chambers for $15 \mathrm{~min}$; this served to habituate the mice with the test procedures and provided a measure of baseline activity. On days 3-15, mice were injected with saline or $2 \mathrm{~g} / \mathrm{kg}$ ethanol. On days $3,7,11$, and 15 , mice were placed in the activity chamber, immediately following the injection, and locomotor activity was monitored for $20 \mathrm{~min}$. 
These tests provided measures of psychomotor sensitization development. From days 13 to 19, animals were kept in their home cages and were not injected. On day 20, all animals received $2 \mathrm{~g} / \mathrm{kg}$, i.p. ethanol to assess the expression of sensitization. Finally, on day 21, all animals were evaluated for locomotor activity after saline to permit comparison of drug-free activity levels before and after repeated ethanol.

Conditioned place preference: apparatus, procedure, and experimental designs

The methodology was previously described (Bahi 2011; Bahi and Dreyer 2011). The apparatus consisted of two rectangular boxes $(30 \mathrm{~L} \times 30 \mathrm{~W} \times 30 \mathrm{Hcm}$ each $)$ separated by a guillotine door. Different visual and tactile cues distinguished the two compartments: black walls and large grid floor for one compartment (A), and white walls and fine grid floor for the other compartment (B). Each experiment consisted of three phases. During the first phase (day 0, preconditioning phase), the guillotine door was kept lifted and each mouse was placed randomly in one or the other compartment and was given access to both compartments of the apparatus for $15 \mathrm{~min}(900 \mathrm{~s})$. The time spent by each mouse in one compartment was recorded. During the second phase, conditioning phase (days 1 to 12 ), the mice were administered ethanol $(2 \mathrm{~g} / \mathrm{kg})$ and immediately placed for $30 \mathrm{~min}$ in a given compartment. On alternate days, mice were administered with saline and immediately placed in the opposite compartment. During the last phase, post-conditioning test, $24 \mathrm{~h}$ after the last treatment, the guillotine door was kept opened and the time spent by each mouse in the drug-paired compartment was recorded during 15 min of observation. The conditions of the post-conditioning test were identical to those of the pre-conditioning test.

Effect of SCH-39166 on the acquisition of ethanol-induced CPP In this experiment, we examined the effect of SCH39166 on the acquisition of ethanol (EtOH)-CPP. Mice were first tested for their baseline preference and alternately conditioned to ethanol in one compartment and saline in the other compartment. To determine the effects of SCH-39166 on the acquisition of ethanol memory, groups of mice received injections of different doses of SCH-39166 (12.5 and $50 \mu \mathrm{g} / \mathrm{kg}$, s.c.) $15 \mathrm{~min}$ before each ethanol conditioning session. After the 12-day conditioning sessions, mice were tested for ethanol-induced CPP as described above. SCH39166 working doses were chosen based on previously published work (Elliot et al. 2003; McCreary and Handley 1999; Witkin et al. 1999).

Effect of LV-siDIR on the acquisition of ethanol-induced $C P P$ In this experiment, mice were tested for their baseline preference as described above. Mice were then stereotaxically injected with either LV-Mock or LV-siD1R in the NAc. After recovery (7 days), mice were conditioned with saline or ethanol as described above and tested for ethanol-induced CPP on day 13.

Effect of $L V$-siD1R on the expression of ethanol-induced $C P P$ Mice were tested for their baseline preference and received 12 days of conditioning sessions. Mice were then stereotaxically injected with either LV-Mock or LV-siD1R in the NAc. After recovery (7 days), mice were tested for ethanol-induced CPP.

\section{Statistical analysis}

The statistics software package SPSS (version 19.0) was used throughout the analysis. Locomotor activity data were analyzed by a mixed three-way analysis of variance (ANOVA), with time as the repeated-measures factor (i.e., day of locomotor activity assessment for behavioral sensitization studies) and treatment (i.e., ethanol or saline administration on days 3-15) and virus group (i.e., LV-Mock or LV-siD1R) as the between-subjects factor. For ethanol drinking analysis, raw data (change in volume) were converted to grams of alcohol, ingested per kilogram of body weight for every data point. This allowed us to determine the exact dose of alcohol consumed by each animal. The data were analyzed with mixed two-way ANOVA using virus group (i.e., LV-Mock or LV-siD1R) as betweensubjects factors. The within-subjects factor was the ethanol (i.e., concentration). For ethanol-induced CPP, data are expressed as mean \pm SEM of time spent during $900 \mathrm{~s}$ of observation in the ethanol-paired compartment during the post-conditioning phase with respect to the time spent during the pre-conditioning phase. To determine the effect of ethanol on CPP, the effects of SCH-39166 on ethanol-induced CPP acquisition and the effect of LV-siD1R on EtOH-CPP acquisition and expression data were analyzed by three-way ANOVA with pretreatment and treatment as independent factors (between-subjects), and pre- and post-conditioning as dependent factors (within-subjects, repeated measures). Post hoc analyses were undertaken if a significant effect of the interaction was found $(p<0.05)$. Comparisons were carried out by Bonferroni post hoc evaluation.

\section{Results}

To study the possible role of endogenous D1R in the NAc in the regulation of ethanol reward, we utilized the lentivirusmediated delivery of siRNA to knock-down the level of the receptor. This technique was extensively used in our laboratory to manipulate the number of genes in the central nervous system (Bahi et al. 2004a, b, 2005a, b, 2006, 2008a, b, c; Bahi 
and Dreyer 2008). Three distinct D1R siRNA sequences were cloned into a lentiviral transfer vector containing that packaged into a lentiviral vector. These viruses were successfully used to knock-down the expression D1R mRNA in the NAc and proteins in the hippocampus (Ortiz et al. 2010).

As shown in Fig. 1a, D1R siRNA lentiviruses (LVsiD1R) significantly reduced the expression level of D1R mRNA in HEK293T cells transfected with D1R overexpressing vector as compared with uninfected cells and cells infected with a control non-specific RNA sequence lentivirus (LV-Mock). Next, we measured the level of D1R mRNA in the NAc after the administration of LV-siD1R and observed a decrease in D1R expression 7 days post-infusion of LV-siD1R, which was still observed 15 and 30 days later (Fig. 1b). A two-way ANOVA revealed a significant effect of virus injection [main effect of virus: $F_{(1,35)}=11.155, p<$ 0.01 ; interaction virus $\times$ time points $\left.F_{(2,35)}=5.844, p<0.05\right]$. Furthermore, the down-regulation of D1R mRNA levels was specific, since infection of the NAc did not result in a decrease in the mRNA levels of the related dopamine a

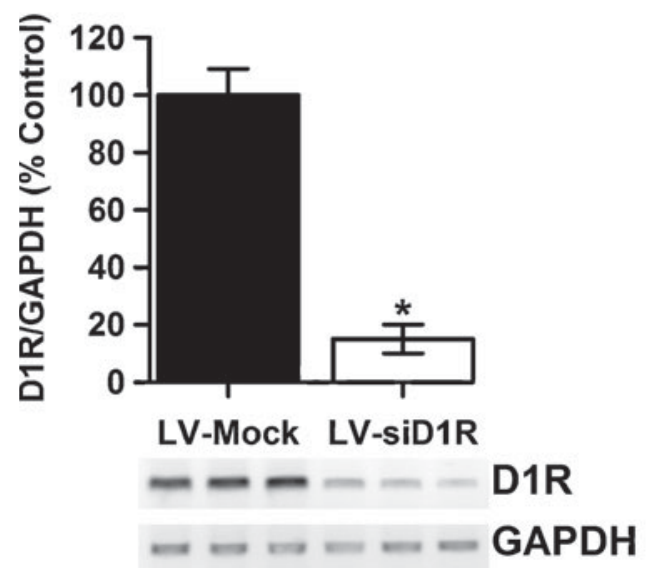

b
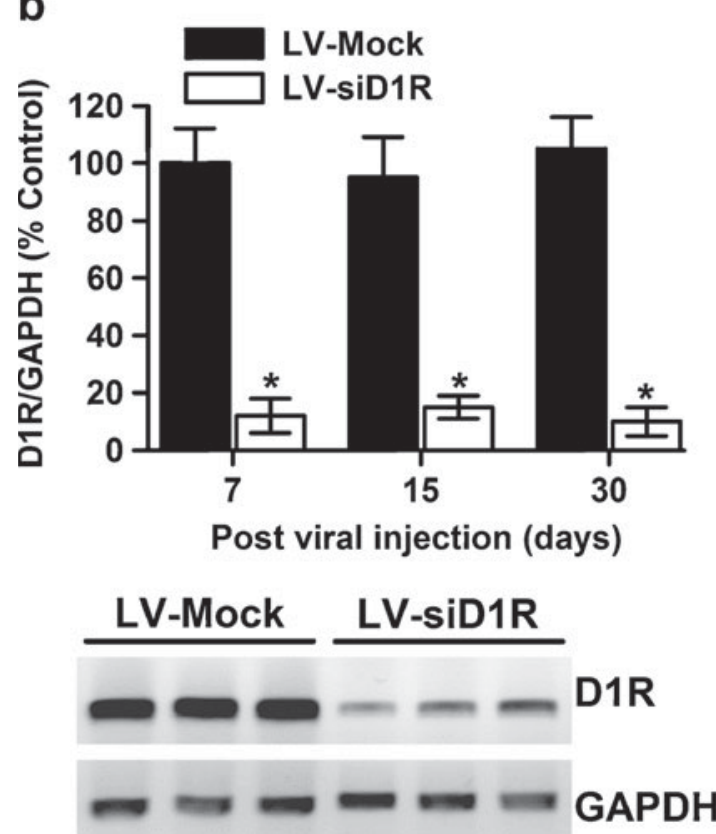

Fig. 1 Knock-down of D1R expression both in vitro and in vivo. a LV-siD1R-siRNA decreases D1R mRNA expression in vitro. D1R overexpressing HEK293T cells were infected with LV-siD1R or LVMock. Cells were collected and used for RT-PCR analysis of D1R expression. Histogram depicts the mean ratios of D1R/GAPDH \pm SEM $(n=5)$. b Mice were stereotaxically infused with LV-siD1R into the NAc. Seven, 15, and 30 days after the microinjection, NAc were
C
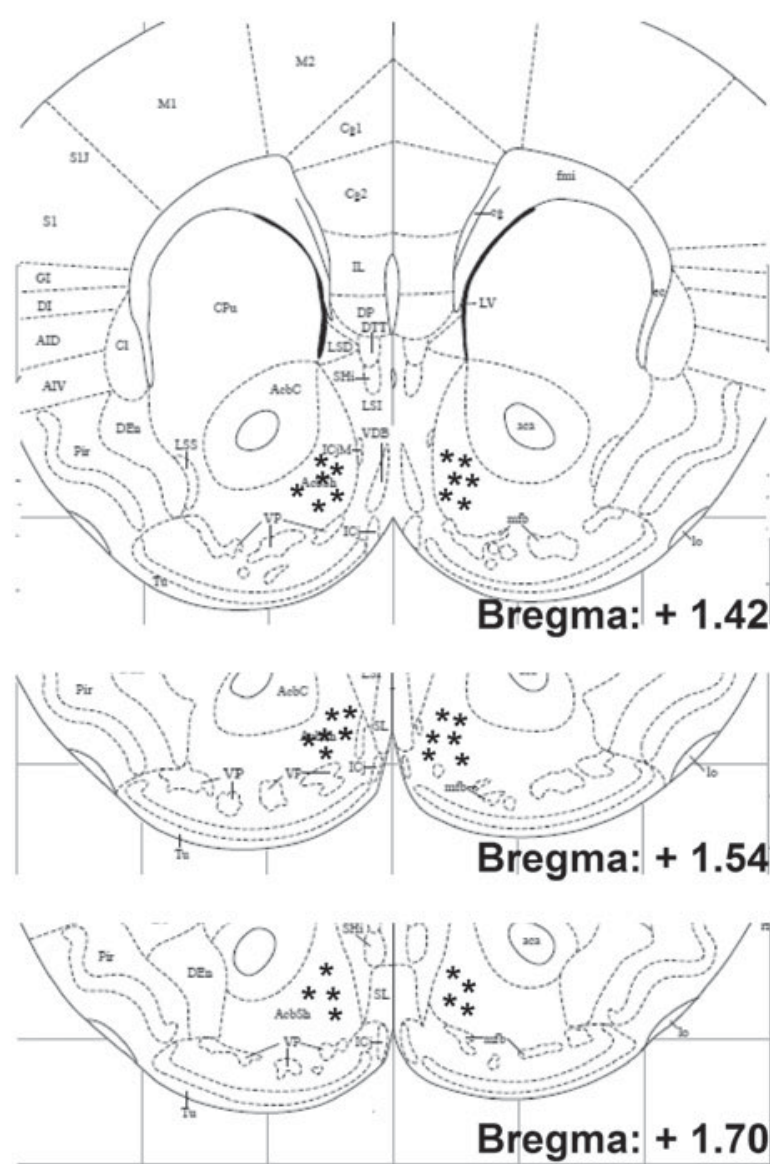

dissected out and used for RT-PCR analysis. LV-siD1R decreased D1R expression in the NAc. Histograms depict the mean ratios of $\mathrm{D} 1 \mathrm{R} / \mathrm{GAPDH} \pm \mathrm{SEM}$ normalized to D1R levels obtained from LVMock animals. The insert is a representative image of D1R mRNA levels from samples collected 30 days after infection by the Mock or siD1R-expressing virus $(n=7),{ }^{*} p<0.01$. $\mathbf{c}$ Schematic representation of the sites of LV-D1R injection into the NAc 
transporters D2R and D3R (data not shown). Together, these results show that lentivirus-mediated D1R siRNAs decrease receptor expression, which corresponds with a decrease in $\mathrm{D} 1 \mathrm{R}$ mRNA level. The placement of injection sites is shown in Fig. 1c.

Dopamine D1 receptor knock-down reduced ethanol consumption

Two-bottle choice drinking paradigm allows measurement of ethanol preference and intake under conditions of voluntary consumption. As shown in Fig. 2a, in a two-bottle choice test, in which mice could drink either water or an ascending series of ethanol concentrations (3\%, 6\%, 9\%, $15 \%$, and $20 \%$ ), mice injected with LV-siD1R displayed decreased ethanol consumption [main effect of virus: $F_{(1,95)}=5.611, p<0.05$; main effect of ethanol concentration: $F_{(4,95)}=12.084, p<0.01$; two-way AVOVA with repeated measures, factors were virus and ethanol concentration]. Results have also shown that blocking D1 receptor reduced ethanol preference as depicted in Fig. $2 \mathrm{~b}$ [main effect of virus: $F_{(1,95)}=7.152, p<0.05$; main effect of ethanol concentration: $\left.F_{(4,95)}=12.084, p<0.01\right]$. For both ethanol consumption and preference, a virus $\times$ ethanol concentration interaction was found. There were no differences in total intake of fluid between LV-Mock and LV-D1R mice as shown in Fig. 2c [main effect of virus: $F_{(1,95)}=0.574, p>0.05$; main effect of ethanol concentration: $\left.F_{(4,95)}=1.095, p>0.05\right]$.

When tested for taste neophobia using non-ethanol tastants, mice lacking D1R did not differ from control mice in preference for saccharin as shown in Fig. 3a [main effect of virus: $F_{(1,36)}=0.781, p>0.05$; main effect of saccharin concentration: $F_{(1,36)}=0.377, p>0.05$; two-way AVOVA with repeated measures, factors were virus and saccharin concentration]. Also D1R knock-down had no effect on quinine preference in mice as depicted in Fig. 3c [main effect of virus: $F_{(1,38)}=0.914, p>0.05$; main effect of quinine concentration: $\left.F_{(1,38)}=6.488, p<0.05\right]$. There were no significant differences in total fluid intake (gram per kilogram per

Fig. 2 Decreased ethanol consumption and preference in LV-siD1R mice. a Ethanol consumption was significantly lower in mutant LV-siD1R compared to LV-Mock mice. b Preference for ethanol was greater in LV-siD1R compared to LV-Mock mice. c The total amount of fluid (water+ethanol) intake was stable across ethanol concentrations for both groups of mice. Data are mean \pm SEM, $n=10-11$ for both groups

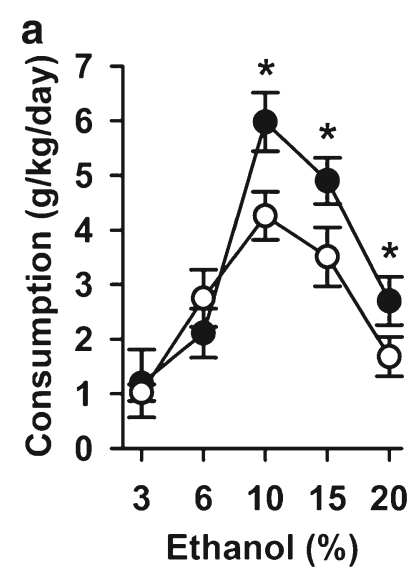

day) between LV-Mock and LV-D1R mice for saccharin [main effect of virus: $F_{(1,36)}=0.187, p>0.05$; main effect of saccharin concentration: $\left.F_{(1,36)}=12.945, p<0.05\right]$ or quinine [main effect of virus: $F_{(1,38)}=0.294, p>0.05$; main effect of quinine concentration: $\left.F_{(1,38)}=0.715, p>0.05\right]$ as shown in panels $b$ and $d$ of Fig. 3, respectively.

Effect of D1 receptor blockade on ethanol-induced psychomotor sensitization

Psychomotor stimulation, resulting in increased locomotor activity, is an indirect measure of mesolimbic dopaminergic system activation (for example, Badiani et al. 1995; Di Chiara and Imperato 1985, 1988; Guan et al. 1985; Kalivas and Stewart 1991; Wise 1987, 1988; Wise and Hoffman 1992). Most drugs of abuse, including ethanol, can induce locomotor activity in experimental animals (Cott et al. 1976; Erickson and Kochhar 1985; Frye and Breese 1981; Larsson and Engel 2004; Matchett and Erickson 1977; Phillips and Shen 1996). In line with the findings of reduced voluntary ethanol drinking, LV-siD1R-injected mice were insensitive to the acute stimulant effects of ethanol ( $2 \mathrm{~g} / \mathrm{kg}$, i.p.) (Fig. 4a). When locomotor activity was measured after a single injection of ethanol, LV-Mock displayed a significant increase in locomotion subsequent to ethanol injection. In contrast, ethanol lacks stimulant properties in LV-siD1Rinjected mice. A two-way ANOVA for virus and ethanol treatment revealed a significant interaction $\left[F_{(2,37)}=8.674\right.$, $p<0.01]$. In addition, as shown in Fig. $4 \mathrm{~b}$, viral-mediated injection of D1R siRNA prior to ethanol treatment reduced the acquisition of ethanol-induced locomotor sensitization. A three-way ANOVA with repeated measures (EtOH dose $\times$ virus $\times$ test day) for data from the LV-siD1R treatment/EtOH sensitization phase (days $3-15$ ) revealed a significant threeway interaction $\left[F_{(3,127)}=6.512 ; p<0.05\right]$. Further analyses revealed significant ethanol dose $\times$ virus interactions on each of the treatment phase days $(3,7,11$, and 15). Mean comparisons showed that the LV-Mock-Ethanol group had significantly greater activity levels compared to the LV-siD1R- b

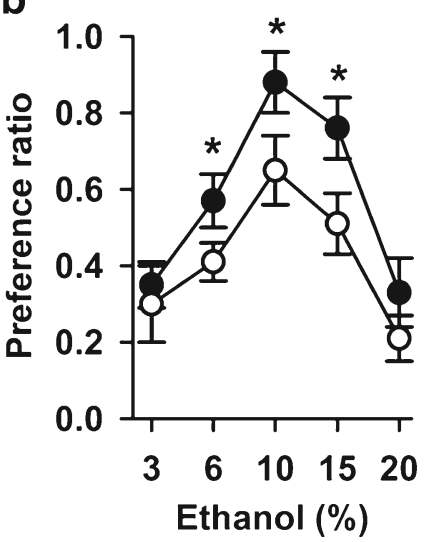

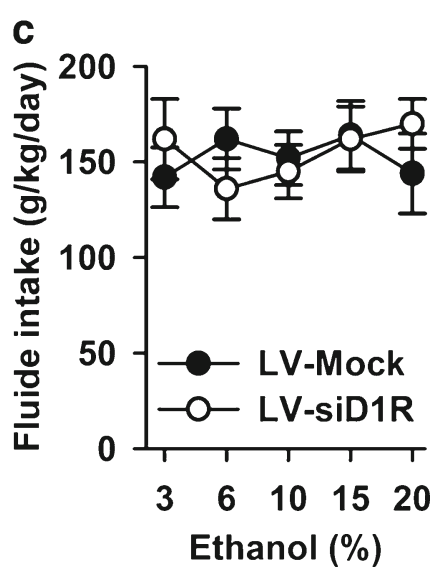


rey. J ivu univiumu in preference for sweet (saccharin) or bitter (quinine) solutions between LV-siD1R compared to LV-Mock mice. a Preference for saccharin solutions was similar in LV-siD1R and LV-Mock mice. b Total fluid (saccharin+water) intake was similar in LV-siD1R and LV-Mock mice. c Preference for quinine was similar in LV-siD1R and LV-Mock mice. d Total fluid (quinine+water) intake was similar in LV-siD1R and LV-Mock mice. Data are mean \pm SEM, $n=10$ - 11 for both groups
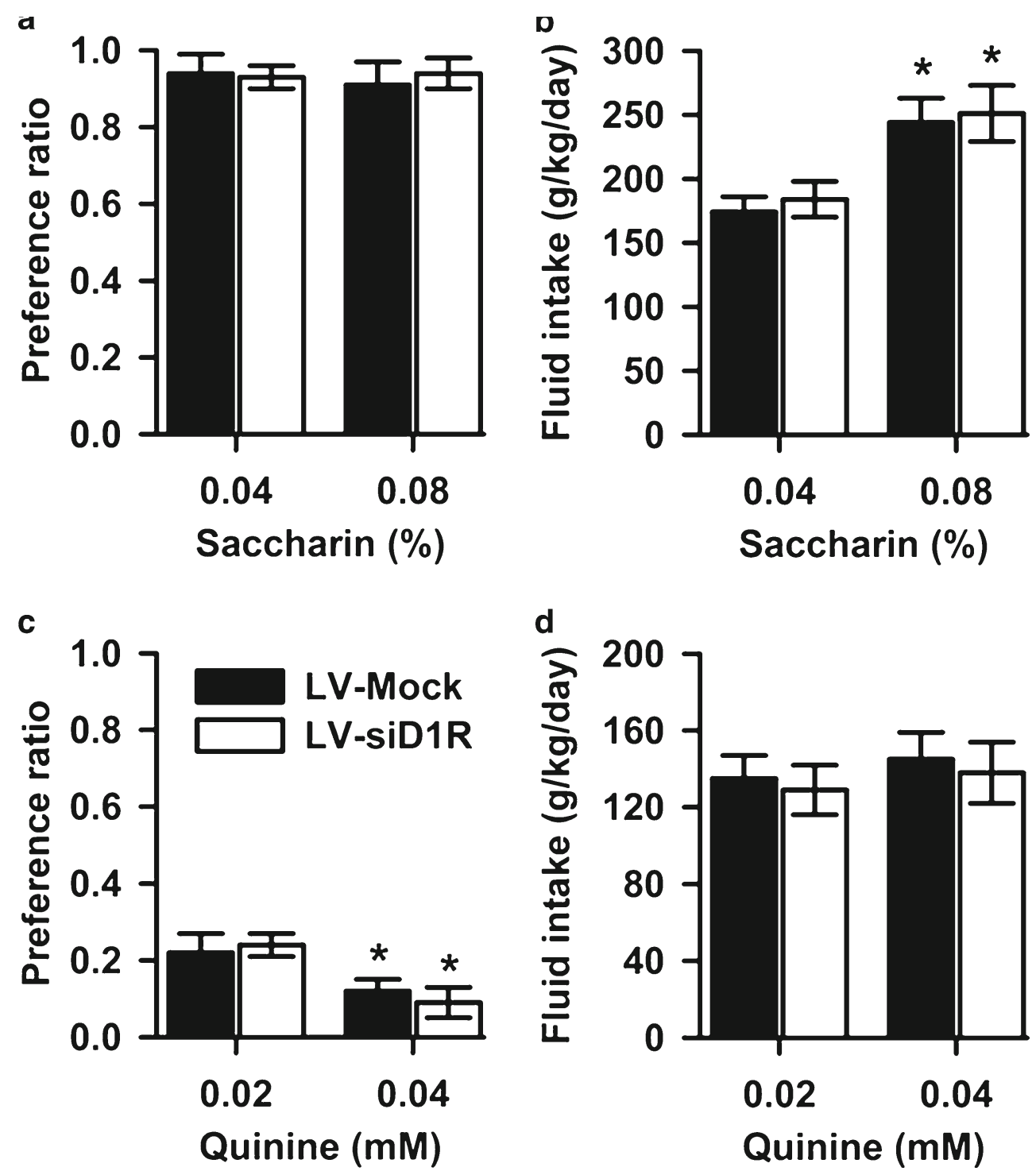

Ethanol group across the entire treatment phase. No significant effect of LV-siD1R pretreatment was found in the LVsiD1R-Saline compared to the LV-Mock-Saline group. The blocking effect of LV-siD1R on ethanol-induced locomotor sensitization was also present in the challenge test (day 20), again indicating that LV-siD1R blocked the acquisition of sensitization to ethanol. A two-way ANOVA (treatment dose $\times$ virus) identified a significant interaction effect $\left[F_{(1,44)}=3.699 ; p<0.05\right]$, and pairwise comparisons confirmed significant sensitization in the LV-Mock-Ethanol, compared to the other three treatment groups. No differences among groups were found on saline test day 21 .

Effects of dopamine D1 receptor blockade on ethanol-induced place preference

Effect of SCH-39166 on the acquisition of ethanol-induced $C P P$ The effects of ethanol-induced CPP and of pretreatment with $\mathrm{SCH}-39166(12.5 \mathrm{mg} / \mathrm{kg})$ are shown in Fig. 5a. Mice receiving ethanol $(2 \mathrm{~g} / \mathrm{kg})$ during conditioning spent more time in the drug-paired compartment during the post-conditioning test $(785.62 \pm 66.32 \mathrm{~s})$ with respect to the pre-conditioning test $(452.31 \pm 61.29 \mathrm{~s}, p<0.001)$ and with respect to the post-conditioning test of the saline group $(451.82 \pm 62.57 \mathrm{~s}, p<0.001)$. Repeated-measures three-way ANOVA of the effects of SCH-39166 on alcohol-induced CPP, with time of conditioning phases as within-subjects (dependent factors) and pretreatment and treatment as between-subjects (dependent factors), revealed a significant effect of conditioning $\left[F_{(1,27)}=6.945, p<0.01\right]$ but not a significant conditioning $\times$ pretreatment $\times$ treatment interaction $\left[F_{(1,27)}=1.032, p>0.05\right]$. Bonferroni post hoc evaluation revealed that ethanol elicited a significant CPP and that pretreatment with SCH-39166 $(12.5 \mu \mathrm{g} / \mathrm{kg})$ did not affect it $(p>0.05)$. The effects of ethanol-induced CPP and of pretreatment with SCH-39166 $(50 \mu \mathrm{g} / \mathrm{kg})$ are shown in Fig. 5 b. 


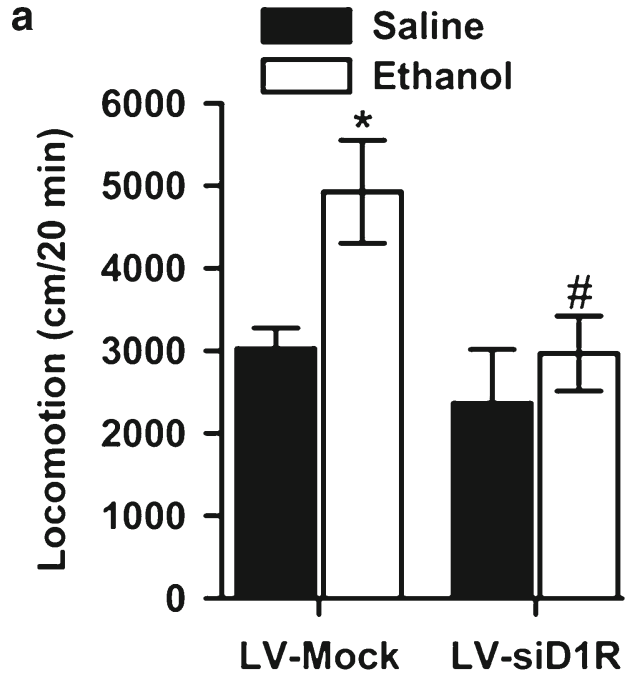

b

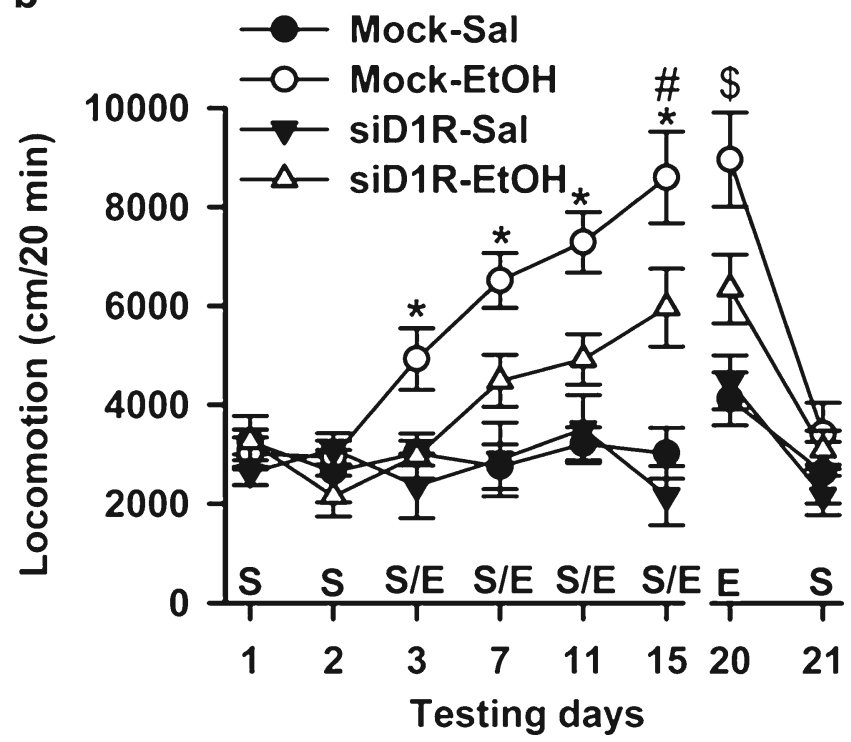

Fig. 4 Dopamine D1-siRNA effects on ethanol-induced psychomotor stimulation. Dopamine D1 receptor blockade blocks the a acute locomotor stimulant response, as well as $\mathbf{b}$ acquisition of locomotor sensitization to ethanol. Distance traveled (centimeter) after saline $(S)$ or $2 \mathrm{~g} / \mathrm{kg}$ ethanol $(E)$ is shown following pre-injection in the NAc with LV-Mock or LVsiD1R prior to activity tests on days $1-15$ ( $n=12-14$ per group). ${ }^{*} p<$ 0.005 for the comparison of LV-Mock-Ethanol vs. LV-siD1R-Ethanol on days $3,7,11$, and 15 . $\# p<0.005$ for the comparison of LV-Mock-Ethanol day 12 vs. day 3. $\$ p<0.005$ for the comparison of LV-Mock-Ethanol vs. the rest of the groups on day 20

Mice receiving ethanol $(2 \mathrm{~g} / \mathrm{kg})$ during conditioning spent more time in the drug-paired compartment during the postconditioning test $(779.35 \pm 65.21 \mathrm{~s})$ with respect to the preconditioning test $(419.88 \pm 39.82 \mathrm{~s}, p<0.001)$ and with respect to the post-conditioning test of the saline group (436.42 $\pm 62.37 \mathrm{~s}, p<0.0186)$. Repeated-measures threeway ANOVA of the effects of SCH-39166 $(50 \mu \mathrm{g} / \mathrm{kg})$ on ethanol-induced CPP, with time of conditioning phases as within-subjects (dependent factors) and pretreatment and
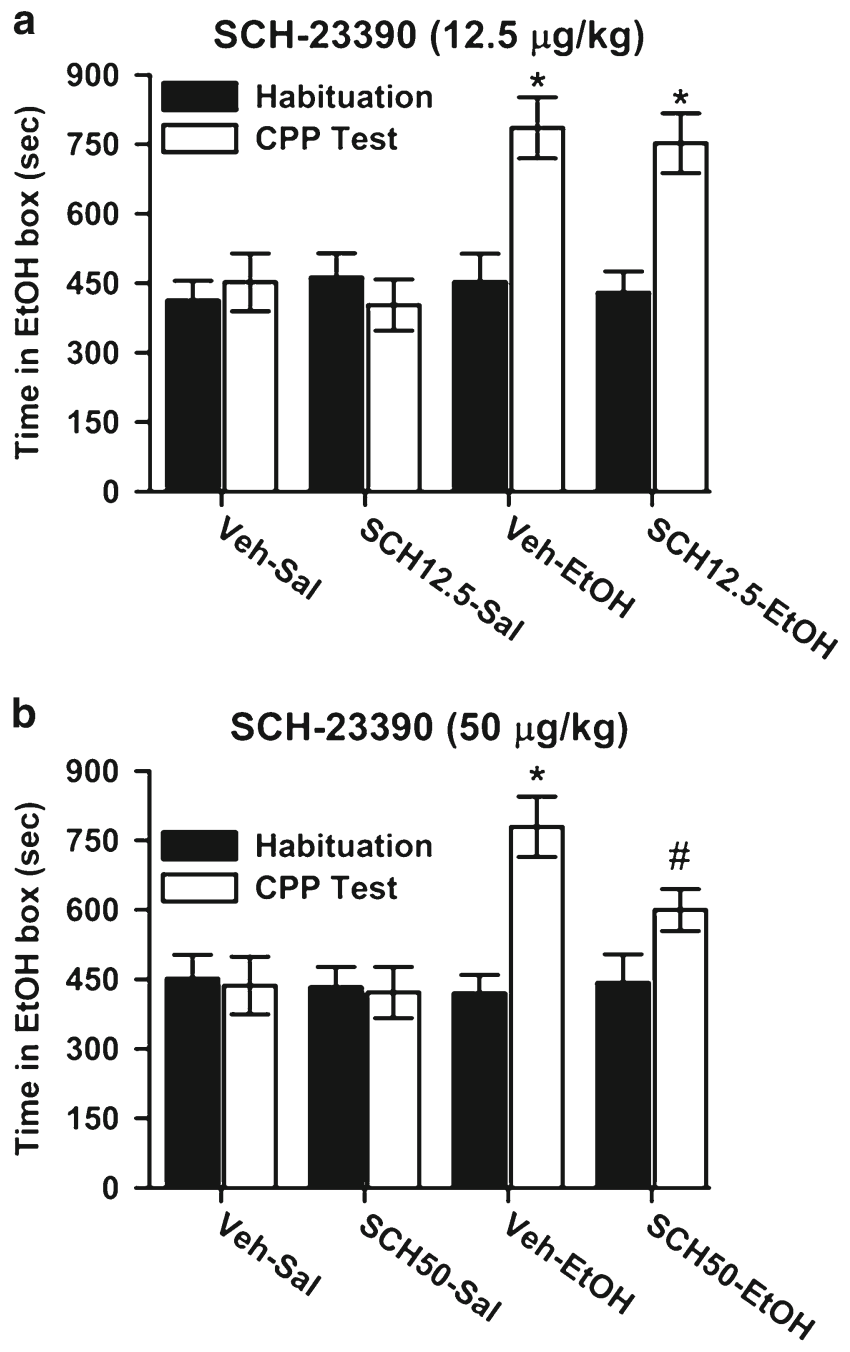

Fig. 5 Effect of SCH-39166 pretreatment on ethanol-induced acquisition of conditioned place preference. Before being conditioned with ethanol $(2 \mathrm{~g} / \mathrm{kg})$, mice were pre-injected with a SCH-39166 $(12.5 \mu \mathrm{g} / \mathrm{kg})$ or b SCH-39166 $(50 \mu \mathrm{g} / \mathrm{kg})$. The number of mice was for Veh-Sal $n=7$ and 7; SCH-Sal $n=8$ and 9; Veh-EtOH $n=7$ and 8 ; SCH-EtOH $n=9$ and 8 . Data are presented as time spent (seconds) \pm SEM in the ethanol-paired compartment. ${ }^{*} p<0.01$ significant differences between the time spent during post-conditioning test when compared with Veh-Sal group; $\# p<$ 0.05 significant differences between the time spent during postconditioning test when compared with Veh-EtOH. SCH SCH-39166, $\mathrm{EtOH}$ ethanol, Sal saline, Veh vehicle

treatment as between-subjects (dependent factors), revealed a significant effect of conditioning $\left[F_{(1,28)}=10.362, p<\right.$ $0.01]$ and a significant conditioning $\times$ pretreatment $\times$ treatment interaction $\left[F_{(1,28)}=4.644, p<0.05\right]$. Bonferroni post hoc analysis revealed that ethanol elicited a significant CPP and that pretreatment with SCH-39166 reduced it $(p<0.05)$.

Effect of $L V$-siD1R on the acquisition of ethanol-induced $C P P$ The effects of D1R knock-down on ethanol-induced CPP acquisition are depicted in Fig. 6a. With respect to the pre-conditioning test, mice receiving ethanol $(2 \mathrm{~g} / \mathrm{kg})$ during 


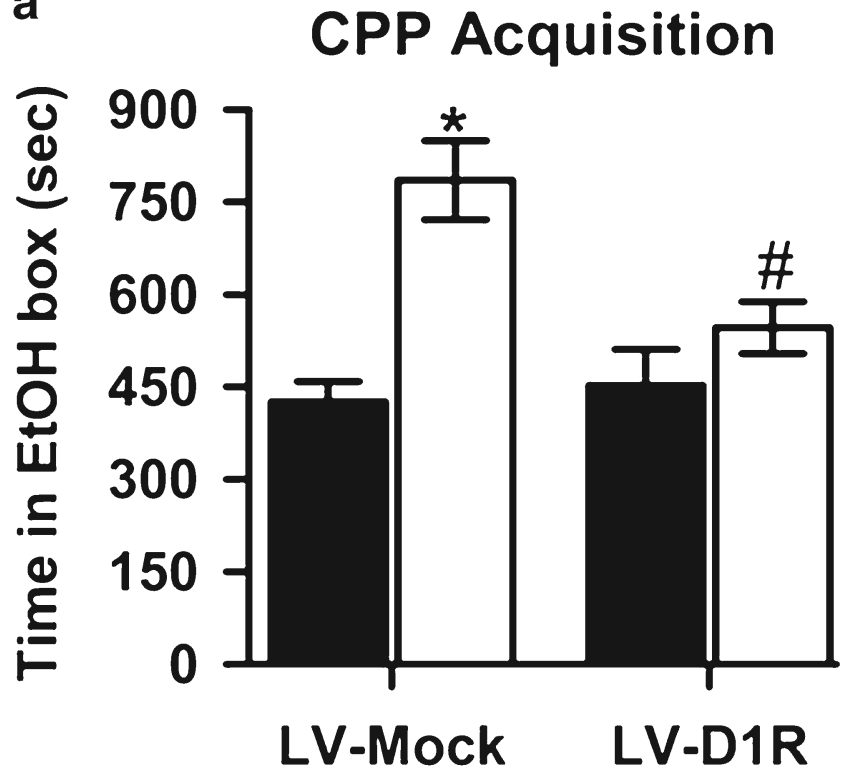

b

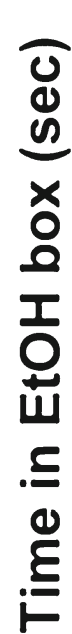

CPP Expression

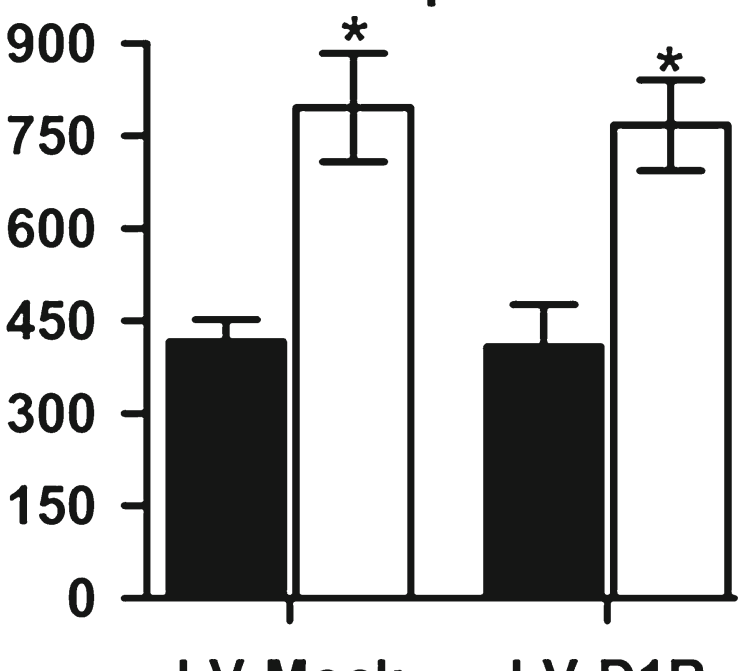

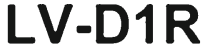

Fig. 6 Effect of D1R knock-down on ethanol-induced acquisition and expression of conditioned place preference. a LV-D1R disrupted the acquisition of ethanol reward memory. A significant difference was found in post-conditioning CPP scores between the LV-Mock group and LV-siD1R group ( $n=10$ per group). ${ }^{*} p<0.01$, compared with preconditioning within the same group; $\# p<0.01$, compared with postconditioning in the LV-Mock group. b LV-D1R had no effect on ethanol-induced CPP expression. No significant difference was found in post-conditioning CPP scores between the LV-Mock group and LVsiD1R group ( $n=10-11$ per group). ${ }^{*} p<0.01$, compared with preconditioning within the same group. All data are presented as time spent (seconds) $\pm \mathrm{SEM}$ in the ethanol-paired compartment, black bars habituation; white bars CPP test

conditioning spent more time in the drug-paired compartment during the post-conditioning test $(p<0.001)$. Repeatedmeasures three-way ANOVA of the effects of LV-siD1R on ethanol-induced CPP, with time of conditioning phases as within-subjects (dependent factors) and virus and treatment as between-subjects (dependent factors), revealed a significant effect of conditioning $\left[F_{(1,18)}=15.661, p<0.01\right]$ and a significant conditioning $\times$ virus $\times$ treatment interaction $\left[F_{(1,18)}=\right.$ 8.928, $p<0.01]$. Bonferroni post hoc analysis revealed that ethanol elicited a significant CPP and that injection with LVsiD1R reduced it $(p<0.05)$.

Effect of $L V$-siDIR on the expression of ethanol-induced $C P P$ The effects of D1R knock-down on ethanol-induced CPP expression are depicted in Fig. 6b. Repeated-measures three-way ANOVA of the effects of LV-siD1R on the expression of ethanol-induced CPP, with time of conditioning phases as within-subjects (dependent factors) and virus and treatment as between-subjects (dependent factors), revealed a significant effect of conditioning $\left[F_{(1,19)}=\right.$ $18.314, p<0.005$ ] but not a significant conditioning $\times$ pretreatment $\times$ treatment interaction $\left[F_{(1,19)}=0.311, p>0.05\right]$. Bonferroni post hoc evaluation revealed that ethanol elicited a significant CPP and that injection of LV-D1R did not affect it $(p>0.05)$.

\section{Discussion}

While dopamine D1 receptor-dependent signaling has been widely implicated in cocaine reward, including conditioned place preference and self-administration, considerably less is known about the role of this receptor in ethanol-induced reward, although it is generally agreed that acute ethanol increases glutamate release via activation of dopamine D1 receptors (Xiao et al. 2009). Co-operative activation of D1-like and D2-like dopamine receptors in the nucleus accumbens shell is necessary to reinstate cocaine seeking in rats (Schmidt and Pierce 2006). For ethanol, studies found that ethanol increases extracellular glutamate levels in the VTA in midbrain slices and in vivo in rats and the increased glutamatergic transmission in turn modulates dopaminergic cell activity in the reward pathway and thus plays a significant role in the processes involved in alcohol addiction (Deng et al. 2009). Ethanol also modulates GABAergic synaptic transmission in the VTA (Xiao et al. 2008a, b). Alcohol dependence has been mainly associated to $\mathrm{GABA}_{\mathrm{A}} \alpha 1, \alpha 3$, and $\alpha 6$ allelic polymorphisms (Sander et al. 1999; Thomas et al. 1998). Also during the formation of drug-stimulus associations, that are critical for cue-induced reinstatement, D1 receptors display unique contributions in mediating dopamine inputs within the basolateral amygdala complex (Andrzejewski et al. 2005; Berglind et al. 2006). However, specific brain regions and mechanisms are still being unknown. 
In the current study, we provide the first evidence that the dopamine D1 receptor is required for ethanol intake in mice. We show that viral-mediated knockdown of D1R mRNA in the nucleus accumbens via RNAi-expressing lentiviral vectors impairs ethanol intake. There were no differences in the total fluid consumed and also no differences in the amount of ethanol consumed between groups prior to surgery. However, after surgery, the LV-siD1R group consumed less ethanol than the control group. Further, we demonstrate that ethanol-induced behavioral sensitization and conditioned place preference acquisition were also affected when D1R mRNA was inhibited. Down-regulation of endogenous D1R using viral-mediated siRNA in the NAc, significantly decreased ethanol-induced behavioral sensitization as well as acquisition, but not expression, of ethanol-induced CPP. This clearly indicates that decreased D1R expression into the NAc leads to reduced ethanol rewarding properties and to lower voluntary alcohol consumption, demonstrating that the D1 receptor pathway within the NAc controls ethanol reward and intake.

Dopamine D1 receptor and voluntary ethanol consumption

We show in the current study that D1R blockade in the NAc reduces ethanol consumption and preference in mice. There is compelling support for the contribution of the D1R in voluntary ethanol intake. In fact, chronic ethanol consumption in rats induced a significant increase in the number of dopamine D1 receptor binding sites in the caudate putamen (Lograno et al. 1993). Also, dopaminergic neurotransmission in the NAc and caudate putamen was highly affected upon ethanol exposure (Nestby et al. 1999), suggesting that these changes in dopamine receptors may be critical for ethanol response. Using genetic mapping in rhesus macaques, D1R polymorphism was associated with ethanol consumption in non-human primates in the context of early environmental stress induced by maternal separation (Newman et al. 2009). In rodents, our findings are in agreement with the documented decrease in ethanol consumption and preference in D1R-deficient mice (D1R ${ }^{-/}$) as compared to their heterozygous $\left(\mathrm{D} 1 \mathrm{R}^{+/-}\right)$and wild-type $\left(\mathrm{D} 1 \mathrm{R}^{+/+}\right)$littermates (El-Ghundi et al. 1998). In the same study, D1 receptor blockade with SCH-23390 reduced alcohol consumption in $\mathrm{D} \mathrm{R}^{+/+}$and $\mathrm{D} 1 \mathrm{R}^{+/-}$mice to the level seen in untreated D1R ${ }^{-/-}$mice (El-Ghundi et al. 1998), suggesting that D1R signaling is highly involved in ethanol-seeking behavior in mice. In the same line, using limited access to $10 \%$ ethanol solution (4 h/day), D1R antagonist SCH-23390 dose-dependently decreased ethanol intake during the first hour of access (Dyr et al. 1993). However, pretreatment of C57BL/6 J inbred mice with D1R agonist (+/-)-1phenyl-2,3,4,5-tetrahydro-(1H)-3-benzazepine-7,8-diol hydrochloride "SKF-38393" reduced voluntary ethanol intake approx. $76 \%$ in comparison to untreated controls (Ng and George 1994). Similarly, using the two-bottle free choice drinking paradigm, both ethanol consumption and preference were reduced by SKF-38393 in rats (Silvestre et al. 1996). Using operant responding behavior, systemic as well as microinjection of SCH-23390, but not SKF-38393, into the NAc reduced alcohol self-administration without affecting response rate (Chaudhri et al. 2009; Eiler et al. 2003; Hodge et al. 1997; Liu and Weiss 2002). Importantly, SKF-38393 pretreatment also decreased responding for saccharin (Cohen et al. 1999) and increased intravenous ethanol self-administration (D'Souza et al. 2003). In the light of these conflicting findings, it is difficult to tease apart the exact role of dopamine D1 receptor but clearly the partial agonist SKF-38393 may have an off target effect acting through D2R (Ruskin et al. 1998). As we used specific knock-down of D1R using shRNA-expressing lentiviral vectors, we propose that antagonizing D1R would be more beneficial to tackle alcohol abuse and alcoholism but further studies are needed to elucidate these conflicting observations.

Dopamine D1 receptor and ethanol-induced conditioned reward and locomotor stimulation

The findings of the current study demonstrate that D1R blockade inhibited ethanol-induced conditioned place preference and behavioral sensitization: D1 receptor-specific shRNA expression in the NAc consistently induced lower activity levels in sensitized animals. When DBA/2 J mice were injected systemically, the D1R partial agonist SKF82958 showed no effect on sensitization to the locomotorstimulating effects of ethanol (Broadbent et al. 2005). Although the i.p. administration of SKF-38393 did not affect the locomotor activity, the intra-NAc administration of SKF-38393 significantly increased the locomotor activity in sensitized mice. In contrast, both i.p. and intra-NAc administration of the D1R antagonist SCH-23390 blocked the expression of ethanol sensitization (Abrahao et al. 2011; Camarini et al. 2011). Taken together, these findings suggest that activation of D1 receptor in the NAc is necessary for the expression of ethanol sensitization.

When tested in ethanol-induced conditioned reward, we have shown that D1R blockade in the NAc attenuated ethanol-induced place preference. This effect was mostly studied in response to cocaine. In fact, large pieces of evidence suggest that dopamine D1R blockade inhibits cocaine-induced place preference (Akins et al. 2004; Baker et al. 1998; Hnasko et al. 2007; Liao et al. 1998; Sershen et al. 2010; Shippenberg and Heidbreder 1995). Our finding is in full agreement with other studies which reported that the D1 antagonist SCH-23390 significantly attenuated the ethanol-induced place preference (Matsuzawa et al. 1999). This effect may require an intact amygdala as the infusion of 
the D1/D2/D3 receptor antagonist (flupenthixol) blocked ethanol CPP but not when it was injected into the NAc (Gremel and Cunningham 2009).

In summary, the present studies demonstrate that prior exposure to ethanol enhances the conditioning of cocaineinduced reward and behavioral sensitization. Viral-mediated shRNA expression studies further suggest the potential involvement of the dopamine Dl receptor in the development of this phenomenon. Given the role of reinforcement processes in the initiation of drug addiction, it is hypothesized that the sensitization that develops to the rewarding effects of alcohol may play an important role in drug craving and the reinstatement of compulsive drug-seeking behavior. Consequently, targeting D1R using SCH-23390-like compounds may be useful to approach ethanol addiction and alcoholism in humans.

Acknowledgments This work was supported by a grant from the United Arab Emirates University (AB) and by grants from the Swiss National Science Foundation 3100-059350 and 3100AO-100686 (JLD).

Disclosure The authors have no financial interests that might be perceived to influence the results or the discussion reported in this article.

\section{References}

Abrahao KP, Quadros IM, Souza-Formigoni ML (2011) Nucleus accumbens dopamine $\mathrm{D}$ receptors regulate the expression of ethanol-induced behavioural sensitization. Int J Neuropsychopharmacol 14:175-185

Akins CK, Levens N, Prather R, Cooper B, Fritz T (2004) Dosedependent cocaine place conditioning and $\mathrm{D} 1$ dopamine antagonist effects in male Japanese quail. Physiol Behav 82:309-315

Altier N, Stewart J (1999) The role of dopamine in the nucleus accumbens in analgesia. Life Sci 65:2269-2287

Andrzejewski ME, Spencer RC, Kelley AE (2005) Instrumental learning, but not performance, requires dopamine D1-receptor activation in the amygdala. Neuroscience 135:335-345

Arias-Carrion O, Stamelou M, Murillo-Rodriguez E, MenendezGonzalez M, Poppel E (2010) Dopaminergic reward system: a short integrative review. Int Arch Med 3:24

Badanich KA, Maldonado AM, Kirstein CL (2007) Chronic ethanol exposure during adolescence increases basal dopamine in the nucleus accumbens septi during adulthood. Alcohol Clin Exp Res 31:895-900

Badiani A, Browman KE, Robinson TE (1995) Influence of novel versus home environments on sensitization to the psychomotor stimulant effects of cocaine and amphetamine. Brain Res 674:291-298

Bahi A (2011) The pre-synaptic metabotropic glutamate receptor 7 "mGluR7" is a critical modulator of ethanol sensitivity in mice. Neuroscience 199:13-23

Bahi A, Fizia K, Dietz M, Gasparini F, Flor PJ (2011) Pharmacological modulation of mGluR7 with AMN082 and MMPIP exerts specific influences on alcohol consumption and preference in rats. Addict Biol. doi:10.1111/j.1369-1600.2010.00310.x
Bahi A, Dreyer JL (2008) Overexpression of plasminogen activators in the nucleus accumbens enhances cocaine-, amphetamine- and morphine-induced reward and behavioral sensitization. Genes Brain Behav 7:244-256

Bahi A, Dreyer JL (2011) Involvement of tissue plasminogen activator "tPA" in ethanol-induced locomotor sensitization and conditionedplace preference. Behav Brain Res 226:250-258

Bahi A, Boyer F, Gumy C, Kafri T, Dreyer JL (2004a) In vivo gene delivery of urokinase-type plasminogen activator with regulatable lentivirus induces behavioural changes in chronic cocaine administration. Eur J Neurosci 20:3473-3488

Bahi A, Boyer F, Kafri T, Dreyer JL (2004b) CD81-induced behavioural changes during chronic cocaine administration: in vivo gene delivery with regulatable lentivirus. Eur J Neurosci 19:1621-1633

Bahi A, Boyer F, Bussard G, Dreyer JL (2005a) Silencing dopamine D3-receptors in the nucleus accumbens shell in vivo induces changes in cocaine-induced hyperlocomotion. Eur J Neurosci 21:3415-3426

Bahi A, Boyer F, Kolira M, Dreyer JL (2005b) In vivo gene silencing of CD81 by lentiviral expression of small interference RNAs suppresses cocaine-induced behaviour. J Neurochem 92:1243-1255

Bahi A, Boyer F, Kafri T, Dreyer JL (2006) Silencing urokinase in the ventral tegmental area in vivo induces changes in cocaine-induced hyperlocomotion. J Neurochem 98:1619-1631

Bahi A, Boyer F, Chandrasekar V, Dreyer JL (2008a) Role of accumbens BDNF and TrkB in cocaine-induced psychomotor sensitization, conditioned-place preference, and reinstatement in rats. Psychopharmacology (Berl) 199:169-182

Bahi A, Kusnecov A, Dreyer JL (2008b) The role of tissue-type plasminogen activator system in amphetamine-induced conditional place preference extinction and reinstatement. Neuropsychopharmacology 33:2726-2734

Bahi A, Kusnecov AW, Dreyer JL (2008c) Effects of urokinase-type plasminogen activator in the acquisition, expression and reinstatement of cocaine-induced conditioned-place preference. Behav Brain Res 191:17-25

Baker DA, Fuchs RA, Specio SE, Khroyan TV, Neisewander JL (1998) Effects of intraaccumbens administration of SCH-23390 on cocaine-induced locomotion and conditioned place preference. Synapse 30:181-193

Ball DM, Murray RM (1994) Genetics of alcohol misuse. Br Med Bull $50: 18-35$

Bassareo V, De Luca MA, Aresu M, Aste A, Ariu T, Di Chiara G (2003) Differential adaptive properties of accumbens shell dopamine responses to ethanol as a drug and as a motivational stimulus. Eur J Neurosci 17:1465-1472

Berglind WJ, Case JM, Parker MP, Fuchs RA, See RE (2006) Dopamine D1 or D2 receptor antagonism within the basolateral amygdala differentially alters the acquisition of cocaine-cue associations necessary for cue-induced reinstatement of cocaine-seeking. Neuroscience 137:699-706

Blanchard BA, Steindorf S, Wang S, Glick SD (1993) Sex differences in ethanol-induced dopamine release in nucleus accumbens and in ethanol consumption in rats. Alcohol Clin Exp Res 17:968-973

Bolos AM, Dean M, Lucas-Derse S, Ramsburg M, Brown GL, Goldman D (1990) Population and pedigree studies reveal a lack of association between the dopamine D2 receptor gene and alcoholism. Jama 264:3156-3160

Bordet R (2004) Central dopamine receptors: general considerations (part 1). Rev Neurol (Paris) 160:862-870

Broadbent J, Kampmueller KM, Koonse SA (2005) Role of dopamine in behavioral sensitization to ethanol in DBA/2 J mice. Alcohol 35:137-148

Bustamante D, Quintanilla ME, Tampier L, Gonzalez-Lira V, Israel Y, Herrera-Marschitz M (2008) Ethanol induces stronger dopamine 
release in nucleus accumbens (shell) of alcohol-preferring (bibulous) than in alcohol-avoiding (abstainer) rats. Eur J Pharmacol 591:153-158

Caille I, Dumartin B, Bloch B (1996) Ultrastructural localization of D1 dopamine receptor immunoreactivity in rat striatonigral neurons and its relation with dopaminergic innervation. Brain Res 730: $17-31$

Camarini R, Marcourakis T, Teodorov E, Yonamine M, Calil HM (2011) Ethanol-induced sensitization depends preferentially on D1 rather than D2 dopamine receptors. Pharmacol Biochem Behav 98:173-180

Casu MA, Colombo G, Gessa GL, Pani L (2002a) Reduced THimmunoreactive fibers in the limbic system of Sardinian alcoholpreferring rats. Brain Res 924:242-251

Casu MA, Dinucci D, Colombo G, Gessa GL, Pani L (2002b) Reduced DAT- and DBH-immunostaining in the limbic system of Sardinian alcohol-preferring rats. Brain Res 948:192-202

Chaudhri N, Sahuque LL, Janak PH (2009) Ethanol seeking triggered by environmental context is attenuated by blocking dopamine D1 receptors in the nucleus accumbens core and shell in rats. Psychopharmacology (Berl) 207:303-314

Cohen C, Perrault G, Sanger DJ (1997) Evidence for the involvement of dopamine receptors in ethanol-induced hyperactivity in mice. Neuropharmacology 36:1099-1108

Cohen C, Perrault G, Sanger DJ (1999) Effects of D1 dopamine receptor agonists on oral ethanol self-administration in rats: comparison with their efficacy to produce grooming and hyperactivity. Psychopharmacology (Berl) 142:102-110

Cooper DC (2002) The significance of action potential bursting in the brain reward circuit. Neurochem Int 41:333-340

Cott J, Carlsson A, Engel J, Lindqvist M (1976) Suppression of ethanol-induced locomotor stimulation by GABA-like drugs. Naunyn Schmiedebergs Arch Pharmacol 295:203-209

Deng C, Li KY, Zhou C, Ye JH (2009) Ethanol enhances glutamate transmission by retrograde dopamine signaling in a postsynaptic neuron/synaptic bouton preparation from the ventral tegmental area. Neuropsychopharmacology 34:1233-1244

Di Chiara G (1997) Alcohol and dopamine. Alcohol Health Res World 21:108-114

Di Chiara G, Imperato A (1985) Ethanol preferentially stimulates dopamine release in the nucleus accumbens of freely moving rats. Eur J Pharmacol 115:131-132

Di Chiara G, Imperato A (1988) Drugs abused by humans preferentially increase synaptic dopamine concentrations in the mesolimbic system of freely moving rats. Proc Natl Acad Sci U S A 85:5274-5278

D'Souza MS, Ikegami A, Olsen CM, Duvauchelle CL (2003) Chronic D1 agonist and ethanol coadministration facilitate ethanolmediated behaviors. Pharmacol Biochem Behav 76:335-342

Dyr W, McBride WJ, Lumeng L, Li TK, Murphy JM (1993) Effects of D1 and D2 dopamine receptor agents on ethanol consumption in the high-alcohol-drinking (HAD) line of rats. Alcohol 10:207-212

Eiler WJ 2nd, Seyoum R, Foster KL, Mailey C, June HL (2003) D1 dopamine receptor regulates alcohol-motivated behaviors in the bed nucleus of the stria terminalis in alcohol-preferring $(\mathrm{P})$ rats. Synapse 48:45-56

El-Ghundi M, George SR, Drago J, Fletcher PJ, Fan T, Nguyen T, Liu C, Sibley DR, Westphal H, O'Dowd BF (1998) Disruption of dopamine D1 receptor gene expression attenuates alcoholseeking behavior. Eur J Pharmacol 353:149-158

Elliot EE, Sibley DR, Katz JL (2003) Locomotor and discriminativestimulus effects of cocaine in dopamine D5 receptor knockout mice. Psychopharmacology (Berl) 169:161-168

Erickson CK, Kochhar A (1985) An animal model for low dose ethanol-induced locomotor stimulation: behavioral characteristics. Alcohol Clin Exp Res 9:310-314
Franklin KBJ, Paxinos G (1996) The mouse brain in stereotaxic coordinates. Academic, New York

Frye GD, Breese GR (1981) An evaluation of the locomotor stimulating action of ethanol in rats and mice. Psychopharmacology (Berl) 75:372-379

Gonzales RA, Job MO, Doyon WM (2004) The role of mesolimbic dopamine in the development and maintenance of ethanol reinforcement. Pharmacol Ther 103:121-146

Grace AA (2000) The tonic/phasic model of dopamine system regulation and its implications for understanding alcohol and psychostimulant craving. Addiction 95(Suppl 2):S119-S128

Gremel CM, Cunningham CL (2009) Involvement of amygdala dopamine and nucleus accumbens NMDA receptors in ethanol-seeking behavior in mice. Neuropsychopharmacology 34:1443-1453

Guan LC, Robinson TE, Becker JB (1985) Sensitization of rotational behavior produced by a single exposure to cocaine. Pharmacol Biochem Behav 22:901-903

Hamdi A, Prasad C (1993) Bidirectional changes in striatal D1dopamine receptor density during chronic ethanol intake. Life Sci 52:251-257

Herz A (1997) Endogenous opioid systems and alcohol addiction. Psychopharmacology (Berl) 129:99-111

Hnasko TS, Sotak BN, Palmiter RD (2007) Cocaine-conditioned place preference by dopamine-deficient mice is mediated by serotonin. J Neurosci 27:12484-12488

Hodge CW, Samson HH, Chappelle AM (1997) Alcohol selfadministration: further examination of the role of dopamine receptors in the nucleus accumbens. Alcohol Clin Exp Res 21:1083-1091

Imperato A, Di Chiara G (1986) Preferential stimulation of dopamine release in the nucleus accumbens of freely moving rats by ethanol. J Pharmacol Exp Ther 239:219-228

Jerlhag E, Landgren S, Egecioglu E, Dickson SL, Engel JA (2011) The alcohol-induced locomotor stimulation and accumbal dopamine release is suppressed in ghrelin knockout mice. Alcohol 45:341-347

Kalivas PW, Stewart J (1991) Dopamine transmission in the initiation and expression of drug- and stress-induced sensitization of motor activity. Brain Res Brain Res Rev 16:223-244

Kiianmaa K, Nurmi M, Nykanen I, Sinclair JD (1995) Effect of ethanol on extracellular dopamine in the nucleus accumbens of alcoholpreferring AA and alcohol-avoiding ANA rats. Pharmacol Biochem Behav 52:29-34

Kohnke MD (2008) Approach to the genetics of alcoholism: a review based on pathophysiology. Biochem Pharmacol 75:160-177

Koob GF, Weiss F (1992) Neuropharmacology of cocaine and ethanol dependence. Recent Dev Alcohol 10:201-233

Larsson A, Engel JA (2004) Neurochemical and behavioral studies on ethanol and nicotine interactions. Neurosci Biobehav Rev 27:713-720

Le Foll B, Gallo A, Le Strat Y, Lu L, Gorwood P (2009) Genetics of dopamine receptors and drug addiction: a comprehensive review. Behav Pharmacol 20:1-17

Li TK (2000) Pharmacogenetics of responses to alcohol and genes that influence alcohol drinking. J Stud Alcohol 61:5-12

Liao RM, Chang YH, Wang SH (1998) Influence of SCH23390 and spiperone on the expression of conditioned place preference induced by d-amphetamine or cocaine in the rat. Chin J Physiol 41:85-92

Liu X, Weiss F (2002) Reversal of ethanol-seeking behavior by D1 and D2 antagonists in an animal model of relapse: differences in antagonist potency in previously ethanol-dependent versus nondependent rats. J Pharmacol Exp Ther 300:882-889

Lograno DE, Matteo F, Trabucchi M, Govoni S, Cagiano R, Lacomba C, Cuomo V (1993) Effects of chronic ethanol intake at a low dose on the rat brain dopaminergic system. Alcohol 10:45-49

Matamales M, Bertran-Gonzalez J, Salomon L, Degos B, Deniau JM, Valjent E, Herve D, Girault JA (2009) Striatal medium-sized spiny 
neurons: identification by nuclear staining and study of neuronal subpopulations in BAC transgenic mice. PLoS One 4:e4770

Matchett JA, Erickson CK (1977) Alteration of ethanol-induced changes in locomotor activity by adrenergic blockers in mice. Psychopharmacology (Berl) 52:201-206

Matsuzawa S, Suzuki T, Misawa M, Nagase H (1999) Involvement of dopamine $\mathrm{D}(1)$ and $\mathrm{D}(2)$ receptors in the ethanol-associated place preference in rats exposed to conditioned fear stress. Brain Res 835:298-305

McBride WJ, Murphy JM, Ikemoto S (1999) Localization of brain reinforcement mechanisms: intracranial self-administration and intracranial place-conditioning studies. Behav Brain Res 101:129-152

McCreary AC, Handley SL (1999) The thyrotrophin-releasing hormone analogue MK771 induces tic-like behaviours: the effects of dopamine D1 and D2 receptor antagonists. Eur J Pharmacol 369:1-9

Melendez RI, Rodd ZA, McBride WJ, Murphy JM (2005) Dopamine receptor regulation of ethanol intake and extracellular dopamine levels in the ventral pallidum of alcohol preferring $(\mathrm{P})$ rats. Drug Alcohol Depend 77:293-301

Muly EC, Maddox M, Khan ZU (2010) Distribution of D1 and D5 dopamine receptors in the primate nucleus accumbens. Neuroscience 169:1557-1566

Nestby P, Vanderschuren LJ, De Vries TJ, Mulder AH, Wardeh G, Hogenboom F, Schoffelmeer AN (1999) Unrestricted free-choice ethanol self-administration in rats causes long-term neuroadaptations in the nucleus accumbens and caudate putamen. Psychopharmacology (Berl) 141:307-314

Newman TK, Parker CC, Suomi SJ, Goldman D, Barr CS, Higley JD (2009) DRD1 5'UTR variation, sex and early infant stress influence ethanol consumption in rhesus macaques. Genes Brain Behav 8:626-630

Ng GY, George SR (1994) Dopamine receptor agonist reduces ethanol self-administration in the ethanol-preferring $\mathrm{C} 57 \mathrm{BL} / 6 \mathrm{~J}$ inbred mouse. Eur J Pharmacol 269:365-374

Nieoullon A, Amalric M (2002) [Dopaminergic receptors: structural features and functional implications]. Rev Neurol (Paris) 158 (Spec no 1):S59-S68

Nurmi M, Sinclair JD, Kiianmaa K (1998) Dopamine release during ethanol drinking in AA rats. Alcohol Clin Exp Res 22:1628-1633

Oreland S, Raudkivi K, Oreland L, Harro J, Arborelius L, Nylander I (2011) Ethanol-induced effects on the dopamine and serotonin systems in adult Wistar rats are dependent on early-life experiences. Brain Res 1405:57-68

Ortiz O, Delgado-Garcia JM, Espadas I, Bahi A, Trullas R, Dreyer JL, Gruart A, Moratalla R (2010) Associative learning and CA3-CA1 synaptic plasticity are impaired in D1R null, Drdla-/- mice and in hippocampal siRNA silenced Drd1a mice. J Neurosci 30:1228812300

Phillips TJ, Shen EH (1996) Neurochemical bases of locomotion and ethanol stimulant effects. Int Rev Neurobiol 39:243-282

Phillips TJ, Brown KJ, Burkhart-Kasch S, Wenger CD, Kelly MA, Rubinstein M, Grandy DK, Low MJ (1998) Alcohol preference and sensitivity are markedly reduced in mice lacking dopamine D2 receptors. Nat Neurosci 1:610-615

Podda MV, Riccardi E, D'Ascenzo M, Azzena GB, Grassi C (2010) Dopamine D1-like receptor activation depolarizes medium spiny neurons of the mouse nucleus accumbens by inhibiting inwardly rectifying $\mathrm{K}+$ currents through a cAMP-dependent protein kinase A-independent mechanism. Neuroscience 167:678-690

Ruskin DN, Rawji SS, Walters JR (1998) Effects of full D1 dopamine receptor agonists on firing rates in the globus pallidus and substantia nigra pars compacta in vivo: tests for D1 receptor selectivity and comparisons to the partial agonist SKF 38393. J Pharmacol Exp Ther 286:272-281

Sander T, Ball D, Murray R, Patel J, Samochowiec J, Winterer G, Rommelspacher H, Schmidt LG, Loh EW (1999) Association analysis of sequence variants of $\operatorname{GABA}(\mathrm{A})$ alpha6, beta2, and gamma2 gene cluster and alcohol dependence. Alcohol Clin Exp Res 23:427-431

Schmidt HD, Pierce RC (2006) Cooperative activation of D1-like and D2-like dopamine receptors in the nucleus accumbens shell is required for the reinstatement of cocaine-seeking behavior in the rat. Neuroscience 142:451-461

Sershen H, Hashim A, Lajtha A (2010) Differences between nicotine and cocaine-induced conditioned place preferences. Brain Res Bull 81:120-124

Shippenberg TS, Heidbreder C (1995) Sensitization to the conditioned rewarding effects of cocaine: pharmacological and temporal characteristics. J Pharmacol Exp Ther 273:808-815

Sibley DR (1999) New insights into dopaminergic receptor function using antisense and genetically altered animals. Annu Rev Pharmacol Toxicol 39:313-341

Silvestre JS, O'Neill MF, Fernandez AG, Palacios JM (1996) Effects of a range of dopamine receptor agonists and antagonists on ethanol intake in the rat. Eur J Pharmacol 318:257-265

Thomas GJ, Harper CG, Dodd PR (1998) Expression of GABA(A) receptor isoform genes in the cerebral cortex of cirrhotic and alcoholic cases assessed by $\mathrm{S} 1$ nuclease protection assays. Neurochem Int 32:375-385

Tiihonen J, Kuikka J, Bergstrom K, Hakola P, Karhu J, Ryynanen OP, Fohr J (1995) Altered striatal dopamine re-uptake site densities in habitually violent and non-violent alcoholics. Nat Med 1:654-657

Tyndale RF (2003) Genetics of alcohol and tobacco use in humans. Ann Med 35:94-121

Velasco M, Luchsinger A (1998) Dopamine: pharmacologic and therapeutic aspects. Am J Ther 5:37-43

Velasco M, Contreras F, Cabezas GA, Bolivar A, Fouillioux C, Hernandez R (2002) Dopaminergic receptors: a new antihypertensive mechanism. J Hypertens Suppl 20:S55-S58

Verheij MM, Cools AR (2008) Twenty years of dopamine research: individual differences in the response of accumbal dopamine to environmental and pharmacological challenges. Eur J Pharmacol 585:228-244

Weiss F, Lorang MT, Bloom FE, Koob GF (1993) Oral alcohol selfadministration stimulates dopamine release in the rat nucleus accumbens: genetic and motivational determinants. J Pharmacol Exp Ther 267:250-258

Wise RA (1987) The role of reward pathways in the development of drug dependence. Pharmacol Ther 35:227-263

Wise RA (1988) The neurobiology of craving: implications for the understanding and treatment of addiction. J Abnorm Psychol 97:118-132

Wise RA, Hoffman DC (1992) Localization of drug reward mechanisms by intracranial injections. Synapse 10:247-263

Witkin JM, Savtchenko N, Mashkovsky M, Beekman M, Munzar P, Gasior M, Goldberg SR, Ungard JT, Kim J, Shippenberg T, Chefer V (1999) Behavioral, toxic, and neurochemical effects of sydnocarb, a novel psychomotor stimulant: comparisons with methamphetamine. J Pharmacol Exp Ther 288:1298-1310

Xiao C, Zhou C, Atlas G, Delphin E, Ye JH (2008a) Labetalol facilitates GABAergic transmission to rat periaqueductal gray neurons via antagonizing betal-adrenergic receptors - a possible mechanism underlying labetalol-induced analgesia. Brain Res 1198:34-43

Xiao C, Zhou C, Li K, Davies DL, Ye JH (2008b) Purinergic type 2 receptors at GABAergic synapses on ventral tegmental area dopamine neurons are targets for ethanol action. J Pharmacol Exp Ther 327:196-205

Xiao C, Shao XM, Olive MF, Griffin WC 3rd, Li KY, Krnjevic K, Zhou C, Ye JH (2009) Ethanol facilitates glutamatergic transmission to dopamine neurons in the ventral tegmental area. Neuropsychopharmacology 34:307-318

Zhou FC, Zhang JK, Lumeng L, Li TK (1995) Mesolimbic dopamine system in alcohol-preferring rats. Alcohol 12:403-412 